УДК 81’374.8-022.218(0.034.2)

https://doi.org/10.52058/2786-4952 -2022-1(6)-75-85

Вакалюк Тетяна Анатоліївна доктор педагогічних наук, професор, професор кафедри інженерії програмного забезпечення, Державний університет «Житомирська політехніка», вул. Чуднівська, 103, м. Житомир, 10005, https://orcid.org/0000-0001-6825-4697

Черниш Оксана Андріївна кандидат філологічних наук, доцент, доцент кафедри теоретичної та прикладної лінгвістики, Державний університет «Житомирська політехніка», вул. Чуднівська, 103, м. Житомир, 10005, https://orcid.org/0000-0002-2010-200X

\title{
АНАЛІЗ ЗАСОБІВ СТВОРЕННЯ ЕЛЕКТРОННОГО БАГАТОМОВНОГО ТЕРМІНОЛОГІЧНОГО СЛОВНИКА
}

Анотація. Наукову розвідку присвячено особливостям створення електронного багатомовного термінологічного словника, покликаного фасилітувати міжнародну наукову співпрацю, а відтак сприяти науковотехнічному прогресу. Автори наголошують на особливостях зазначено типу словника та наводять низку його переваг. Відтак електронний багатомовний термінологічний словник цінується за компактність, динамічність, актуальність, мультимедійність, універсальність та багатофункціональність. Словник вирізняється значним обсягом словникової бази, а також швидкою й зручною системою пошуку необхідної інформації. У статті проаналізовано наявні засоби укладання електронного багатомовного словника, зокрема PolyDicML 3.0, TLex (Tshwanelex), Dictionary Maker, Softlex, FLEx, LingTransSoft, Lingo 4.0, Dictionary Organizer Deluxe 4.12, Alternate Dictionary 2.980, WeSay. Значна увага звертається на функціональність зазначених засобів створення електронного багатомовного словника, а також їх зручність у використанні, зрозумілий інтерфейс. Встановлено, що переважна більшість розглянутих засобів $є$ ефективними у лексикографічній роботі, оскільки надалі сприяє якісній роботі перекладача-синхроніста та перекладача вузького профілю. Досліджені засоби створення електронного словника дозволяють надати вичерпну інформацію щодо особливостей функціонування певної лексеми, зокрема транскрипцію відповідно до IPA, антонімію та синонімію, відмітку про частину мови, а також навести приклади її вживання у контексті. Ці засоби уможливлюють якісне укладання бізнес-глосаріїв, підручників 3 наукової термінології або словників користувача. Автори зазначають, що представлені засоби створення електронного багатомовного термінологічного словника застосовуються переважно для укладання тлумачних i/aбo двомовних електронних словників. Відповідно існує перспектива подальших 
наукових досліджень у знаходженні можливостей укладання електронного багатомовного термінологічного словника із залученням п'яти мов.

Ключові слова: електронні словники, засоби створення електронних словників, інформаційно-комунікаційні технології.

Vakaliuk Tetiana Anatoliivna Doctor of Pedagogical Sciences, Professor, Professor of Software Engineering Department, Zhytomyr Polytechnic State University, Chudnivska St., 103, Zhytomyr, 10005, https://orcid.org/0000-0001-6825-4697

Chernysh Oksana Andriivna Candidate of Philological Sciences, Associate Professor, Associate Professor at the Department of Theoretical ad Applied Linguistic, Zhytomyr Polytechnic State University, Chudnivska St., 103, Zhytomyr, 10005, https://orcid.org/0000-0002-2010-200X

\section{ON THE MEANS OF ELECTRONIC MULTILINGUAL TERMINOLOGICAL DICTIONARY COMPILATION}

Abstract. Scientific article is dedicated to the analysis of electronic multilingual terminological dictionary peculiarities. Electronic multilingual terminological dictionary is aimed to facilitate international scientific cooperation, and thus promote scientific and technological progress. Additionally, the authors emphasize electronic dictionary distinctive features and highlight a number of its advantages. Thus, electronic multilingual terminological dictionary is valued for its compactness, dynamism, relevance, multimedia, versatility and multifunctionality. The dictionary has a large scope of vocabulary items, as well as a user-friendly search system for finding the necessary information. The article analyzes current tools for electronic multilingual dictionary compilation, PolyDicML 3.0, TLex (Tshwanelex), Dictionary Maker, Softlex, FLEx, LingTransSoft, Lingo 4.0, Dictionary Organizer Deluxe 4.12, Alternate Dictionary 2.980, WeSay including. Furthermore, considerable attention is given to the functionality of electronic multilingual dictionary compilation tools, as well as their user-friendly interface. Moreover, it is established that electronic multilingual dictionary compilation tools are effective in lexicographic work as they significantly contribute to translators and localizers' quality work. Electronic multilingual dictionary compilation tools make it possible to provide thorough information about the peculiarities of lexical item use including transcription according to IPA, antonyms and synonyms, part of speech indication, as well as examples of its use in context. These tools enable high-quality compilation of business glossaries, textbooks on scientific terminology or user dictionaries. In addition, the authors highlight that the tools analyzed are mostly used for explanatory and / or bilingual electronic dictionaries compilation. Accordingly, the prospects for further research include finding the ways to compile a 5-language electronic multilingual terminological dictionary. 
Keywords: electronic dictionaries, means of electronic dictionaries compilation, information and communication technologies.

Постановка проблеми. XXI століття характеризується стрімким розвитком інформаційних технологій, посиленою глобалізацією та постійним науково-технічним прогресом. Відтак відчутною є потреба у систематичній актуалізації набутих знань та фіксації нових досягнень й надбань, що сприятиме гармонійному розвитку суспільства. Електронний багатомовний термінологічний словник безперечно є не лише одним 3 найкращих джерел фіксації науково-технічного прогресу, але й інструментом передачі знань наступним поколінням. Важливість зазначеного типу лексикографічного видання очевидна, зокрема: - компактність, універсальність та багатофункціональність; - значний обсяг словникової бази; - швидка й зручна система пошуку необхідної інформації; - локалізація релевантної інформації, наприклад, наявність гіпертекстових посилань із зазначенням синонімії, антонімії, омонімії тощо; - актуальність та динамічність, що включає можливість постійного своєчасного оновлення інформації та вилучення лексем, що вийшли з ужитку; - можливість вибору низки необхідних опцій; наявність відповідних утиліт, що уможливлюють оперативне оновлення наведеної інформації; - мультимедійність, що передбачає озвучення слів, наведення необхідного ілюстративного матеріалу (фото, відео, графічні елементи); - можливість додаткового використання низки тлумачних, енциклопедичних, спеціальних та інших словників тощо. Відповідно наразі актуальність укладання електронного багатомовного термінологічного словника зростає, а відтак виникає нагальна потреба аналізу та систематизації існуючих засобів його створення.

Аналіз останніх досліджень i публікацій. Питанням дослідження особливостей створення електронного багатомовного словника займалася значна когорта як українських (О.С Андрощук, Ю.Г. Білецька, С.I. Головащук, М.Г. Гордієнко, Н.П. Дарчук, Н.Ю. Етенко, О.С. Ковальчук, А.О. Маслюк, Л.І. Морська, К.Т. Селіверстова, Н.М. Сінкевич, Г.А. Чередніченко, Т.Є. Шевченко, А.В. Шиба), так і зарубіжних (М.О. Лангебах, Т.А. Сарангова, М.В. Троссель, В.В. Морковкін, С.В. Гріньов-Гриневич, Т.С. Борщевська, Г. Бернгенгольц) науковців. Зокрема досліджено завдання сучасних електронних багатомовних словників [7], розглянуто типологію електронних словників [4], описано принципи створення [3] та специфіку укладання електронних навчальних словників вузьких спеціалізації [5], представлено комп'ютерно-технологічні аспекти створення сучасних лексикографічних систем [6], проілюстровано переваги та недоліки використання електронних лексикографічних видань [1], встановлено перспективні напрямки розвитку сучасної комп’ютерної лексикографії [2]. Однак відчувається необхідність систематизації існуючих засобів створення електронних багатомовних термінологічних словників задля покращення їхньої якості та вдосконалення 
самого процесу їхнього укладання. Зазначений аналіз дозволить виокремити позитивні та негативні дистинктивні риси засобів укладання словників та сприятиме поліпшенню інструментарію створення електронного багатомовного термінологічного словника.

Таким чином, метою нашої наукової розвідки $є$ аналіз наявних засобів створення електронного багатомовного термінологічного словника.

Виклад основного матеріалу. Зважаючи на постійно зростаючу необхідність використання користувачами електронних багатомовних словників, наразі існує низка засобів їх створення. Одним 3 таких засобів $є$ PolyDicML 3.0, який містить два модулі (окремо для введення та редагування словникових баз та їхнього відтворення на дисках). Варто зазначити, що PolyDicML 3.0 має низку вагомих переваг, до яких варто віднести: - наявність власне редактора словникових статей; - можливість конвертувати словникові бази у текстовий формат для подальшого редагування матеріалу; - можливість об’єднання декількох словникових баз та додавання окремих коментарів; додаткова опція завантаження зображень, графіків, формул, аудіо та відео матеріалу; - можливість відтворення окремих елементів мови (антонімів, синонімів, транслітерації, транскрипції, граматичних та стилістичних коментарів, різних абревіатур і скорочень тощо); - простота та зручність у використанні, що значно пришвидшує процес пошуку необхідної лексеми. Не менш затребуваним є засіб TLex (також відомий як TshwaneLex). TLex $є$ багатофункціональним засобом укладання електронних багатомовних словників [16] (див. рис. 1).

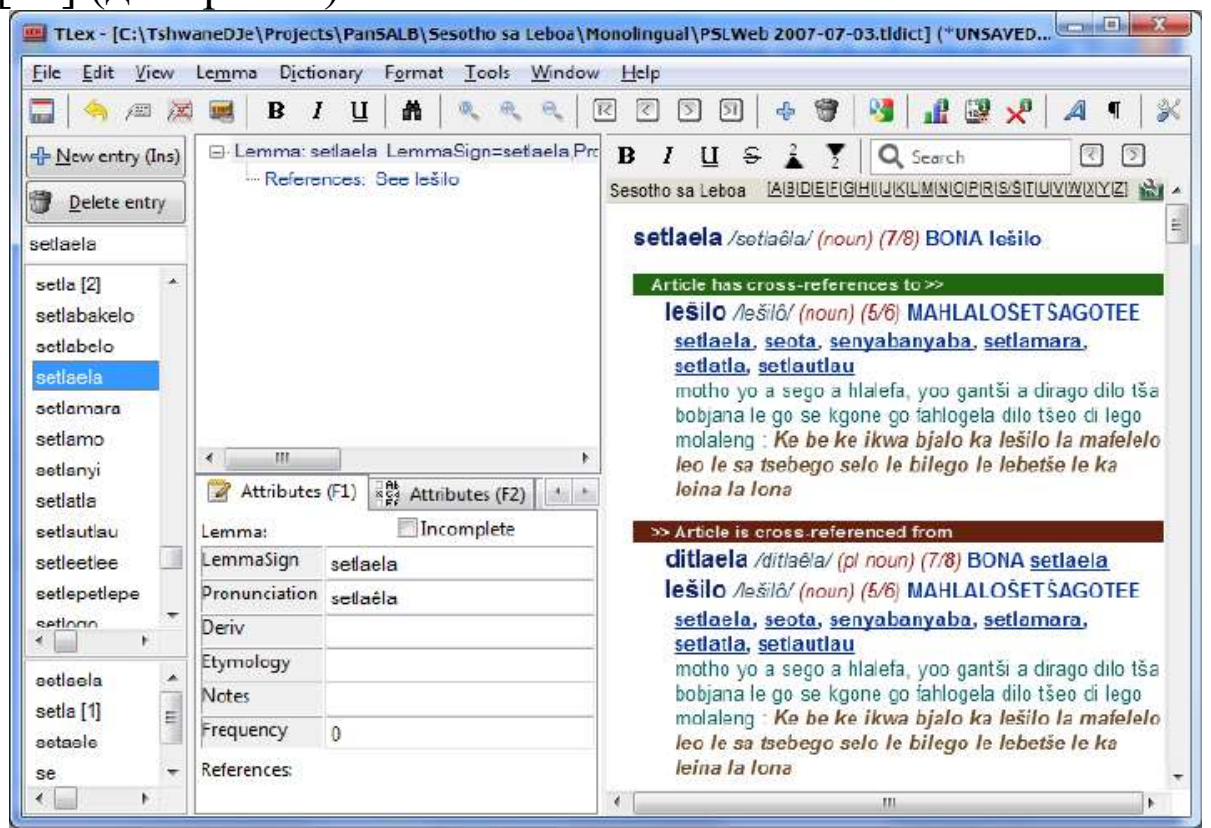

Puc. 1. TLex (TshwaneLex).

Зазначений засіб дозволяє укладати словники будь-якою мовою та включає в себе такі функції: - попередній перегляд словникової статті; можливість встановлення усіх налаштувань; - експорт словникових статей у текстовий формат (MS Word) для подальшого редагування матеріалу; - 
можливість спільної роботи в мережі; - наявність окремого модулю для набору (Adobe InDesign); - можливість створення окремого словника для подальшого розміщення в мережі Інтернет або як окремого додатка тощо. Дистинктивною особливістю цього засобу $є$ можливість автоматичного відстеження перехресних посилань у словникових статтях [16]. Окрім того, TLex дозволяє зі створеного електронного багатомовного словника створити його друковану версію. До того ж, наявна також можливість попереднього перегляду статті в режимі реального часу. Слушною видається можливість налаштування мови, якою буде відображатись додаткова інформація. Не менш важливою перевагою TLex є функція пошуку в межах усього словника.

Саме цей засіб створення електронного багатомовного словника дозволяє порівняти різні версії словникових баз даних, а також об'єднувати їх. TLex також дозволяє долучати необхідні аудіо- та відео- матеріали, а також графічні елементи та зображення.

Для забезпечення цілісності даних, TLex має можливість обмеження доступу користувачів для редагування словникових статей, а також відображення статистики по роботі різних користувачів (моніторинг діяльності користувача). Доречним вважаємо унікальну можливість перегляду статистичних даних по кількості постійних відвідувачів і пошуків за певним діапазоном часу (день, тиждень, місяць тощо) (див. рис. 2).

\begin{tabular}{|c|c|c|c|c|c|c|c|c|c|}
\hline \multicolumn{10}{|c|}{ Details } \\
\hline Day & Total & Norm: & Inverse & Graphs (all) & Total & Normal & Inverse & Visitors & \\
\hline $\begin{array}{l}2003-07- \\
07\end{array}$ & 293 & 114 & 179 & 三人 & & $\bar{E}$ & E & E & 734.01 \\
\hline $\begin{array}{l}2003-07- \\
08\end{array}$ & 251 & 113 & 138 & 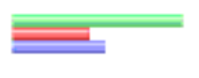 & $=$ & $\underline{\underline{E}}$ & ए & 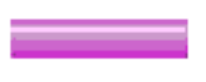 & 604.18 \\
\hline $\begin{array}{l}2003-07- \\
09\end{array}$ & 270 & 146 & 124 & $\overline{\underline{\underline{ }}}$ & E & $\bar{\square}$ & $\square$ & $\square$ & 495.51 \\
\hline $\begin{array}{l}\text { 2003-07- } \\
10\end{array}$ & 123 & 49 & 74 & $\equiv$ & 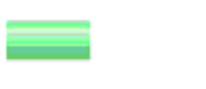 & 를 & $\equiv$ & $\bar{\square}$ & 235.36 \\
\hline $\begin{array}{l}2003-07- \\
11\end{array}$ & 318 & 80 & 238 & ב & & $\square$ & 를 & 른 & 714.48 \\
\hline $\begin{array}{l}2003-07- \\
12\end{array}$ & 63 & 24 & 39 & ㄹ & E & E & 를 & E & 115.73 \\
\hline $\begin{array}{l}2003-07- \\
13\end{array}$ & 116 & 49 & 67 & $\equiv$ & $\bar{E}$ & 를 & $=$ & E & 1011.6 \\
\hline $\begin{array}{l}7 \text { days } \\
\text { Average }\end{array}$ & $\begin{array}{l}1434 \\
: 204.86\end{array}$ & $\begin{array}{c}575 \\
682.14\end{array}$ & $\begin{array}{l}859 \\
122.71\end{array}$ & & & & & 42.43 & \\
\hline
\end{tabular}

Puc. 2. Статистичний дані загальної кількості пошуків та кількості відвідувачів (встановлений діапазон дати/часу).

Широкого застосування набув Dictionary Maker, безкоштовний засіб для створення електронних словників [10], який доступний для використання (для створення словника) лише англійською мовою. Варто зазначити, що це засіб для створення звичайних словників, а не тлумачних, відповідно його функціонал значно менший (див. рис. 3).

Наступний проаналізований засіб для створення електронних словників Softlex [3] поєднує в собі базу даних $N o S Q L$, яка оптимізована саме для зберігання словникових даних, і спеціального текстового редактора, який дозволяє вводити складні дані словника [3]. 
Особливістю цього засобу є можливість експортування даних в XML або у файл, при цьому зберігається уся структура словника. Прикметною ознакою Softlex можна вважати: - можливість здійснення пошуку за відповідними параметрами; - сортування лексикографічної інформації; - опція зберігання складних словникових структур; - наявність лексикографічних елементів, фонетичної транскрипції тощо; - представлення метаданих, коментарів; розподіл прав користувачів тощо [3]. Крім того, розробники зазначають, що невдовзі планують представити цю послугу у хмарі - через модель SaaS.

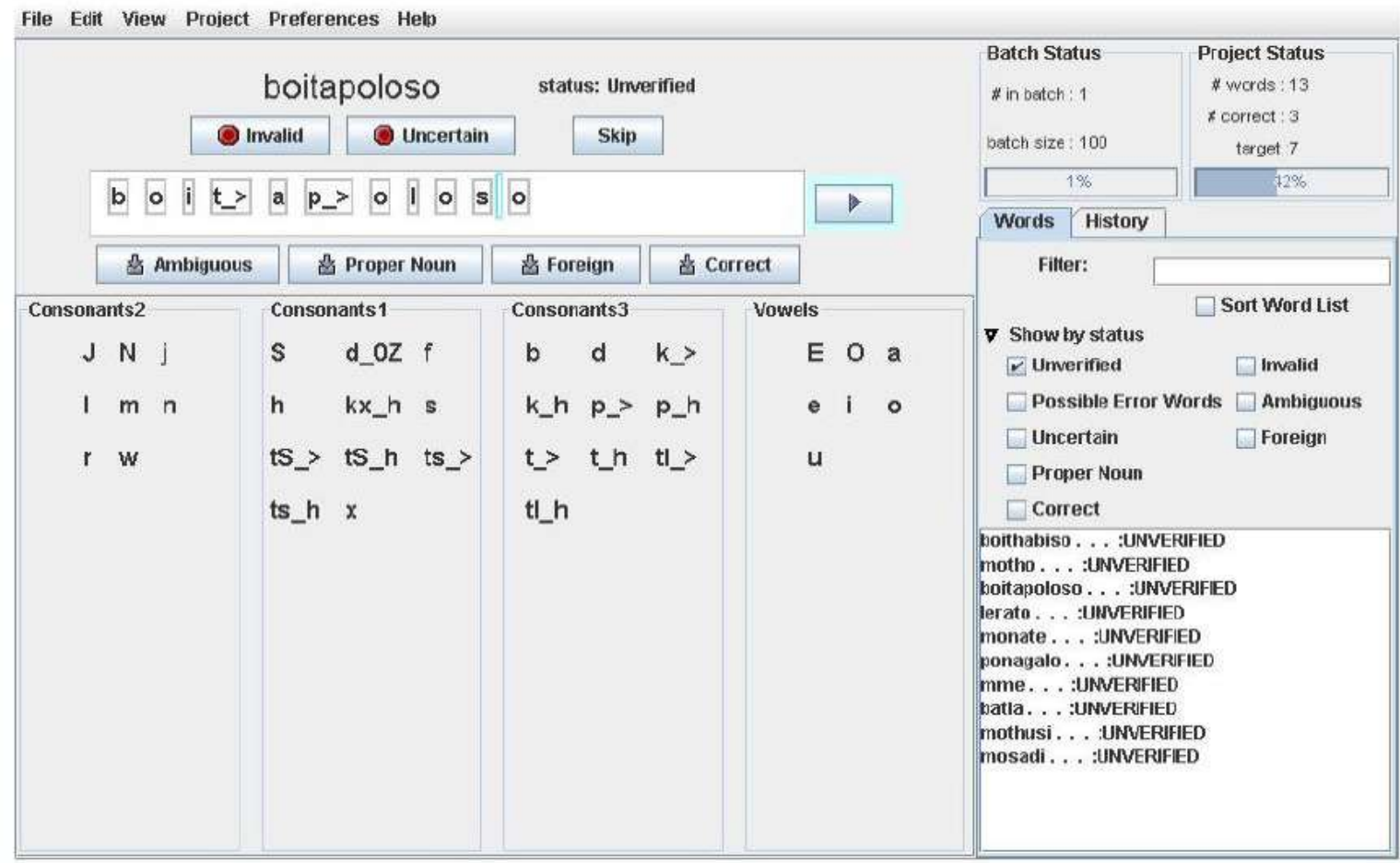

Puc. 3. Інтерфейс Dictionary Maker

Розглянемо FLEx (FieldWorks Language Explorer) як засіб створення електронного багатомовного словника, що включає компоненти лексичних і текстових інструментів SIL FieldWorks [12]. Це програма 3 відкритим вихідним кодом, розроблена в допомогу лінгвістам здійснювати відповідну лексикографічну роботу, зокрема: - вводити та актуалізувати лексичну інформацію; - налаштовувати та експортувати словники; працювати з інтелінійними текстами; - аналізувати особливості дискурсу; грунтовно вивчати морфологічні особливості відповідних лексичних одиниць; - впорядковувати екстралінгвістичну інформацію, необхідну для розуміння та правильного вживання відповідної лексичної одиниці тощо.

Широке застосування має також такий засіб створення електронного багатомовного словника як LingTransSoft [14]. LingTransSoft $є$ одним 3 найактуальніших інструментів аналізу даних для лінгвістів, спрямований на редагування лексичних даних, синтаксичний розбір та інтерлінійність тексту. Однак функціональність цього засобу не обмежується перерахованим вище. 
Цей засіб може бути успішно використаний для опрацювання будь-яких даних. Перевага LingTransSoft відчутна у його можливостях, зокрема: застосування відповідних критеріїв пошуку та відбору необхідної лексичної інформації; - багаторазовий перегляд бази даних; - перегляд бази у вигляді систематизованої таблиці; - відображення підмножин бази даних тощо. LingTransSoft може опрацьовувати будь-яку кількість сценаріїв в одній базі даних. При цьому кожен скрипт має свої особливості шрифту та сортування.

LingTransSoft цінується за - морфонологічний аналізатор, який сприяє грунтовному аналізу морфофонемних процесів; - складову формулу слова, що уможливлює опис усіх можливих афіксальних моделей слова та інші.

Вартий уваги Lingo 4.0, призначений для створення одно- та багатомовних словників, глосаріїв, а також їх постійної та систематичної актуалізації [13]. Програма зручна у використанні з будь-яким текстовим редактором Windows та має корисні функції імпорту та експорту, що дозволяє конвертувати дані відповідним чином. Lingo 4.0 користується популярністю як у перекладачів-синхроністів, так і перекладачів вузького профілю та знаний в усьому світі.

Розглянемо програмне забезпечення для управління базою даних Dictionary Organizer Deluxe 4.12, яке дозволяє створити термінологічний словник або глосарій [11]. Dictionary Organizer Deluxe 4.12 має цілком зрозумілий інтерфейс, зручний у використанні та призначений переважно для укладання бізнес-глосаріїв, підручників з наукової термінології або словників користувача (див. рис. 4).

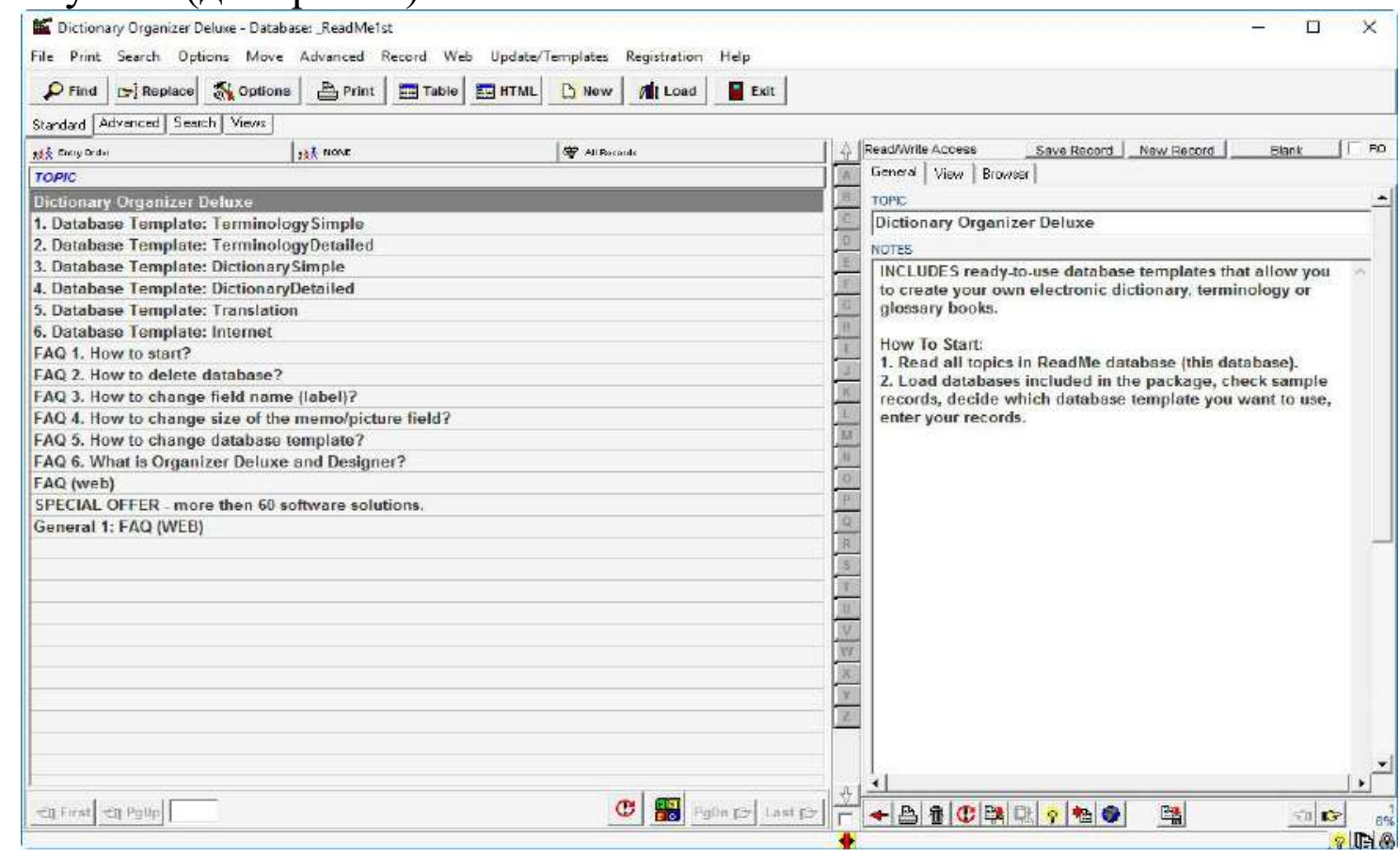

Puc. 4. Інтерфейс Dictionary Organizer Deluxe 4.12

Alternate Dictionary 2.980 інтуїтивна програма, яка завдяки зручному інтерфейсу дозволяє укладати словники у лічені кліки мишки [8]. Програма має декілька функціональних модулів, що передбачає як введення нового 
терміну, так і редагування вже існуючого. Alternate Dictionary 2.980 дозволяє зосередити увагу на відповіднику цільової мови у розрізі не лише слова, але й фрази. Перевагою також є можливість закріплення слів та фраз шляхом виконання низки вправ (див. рис. 5).

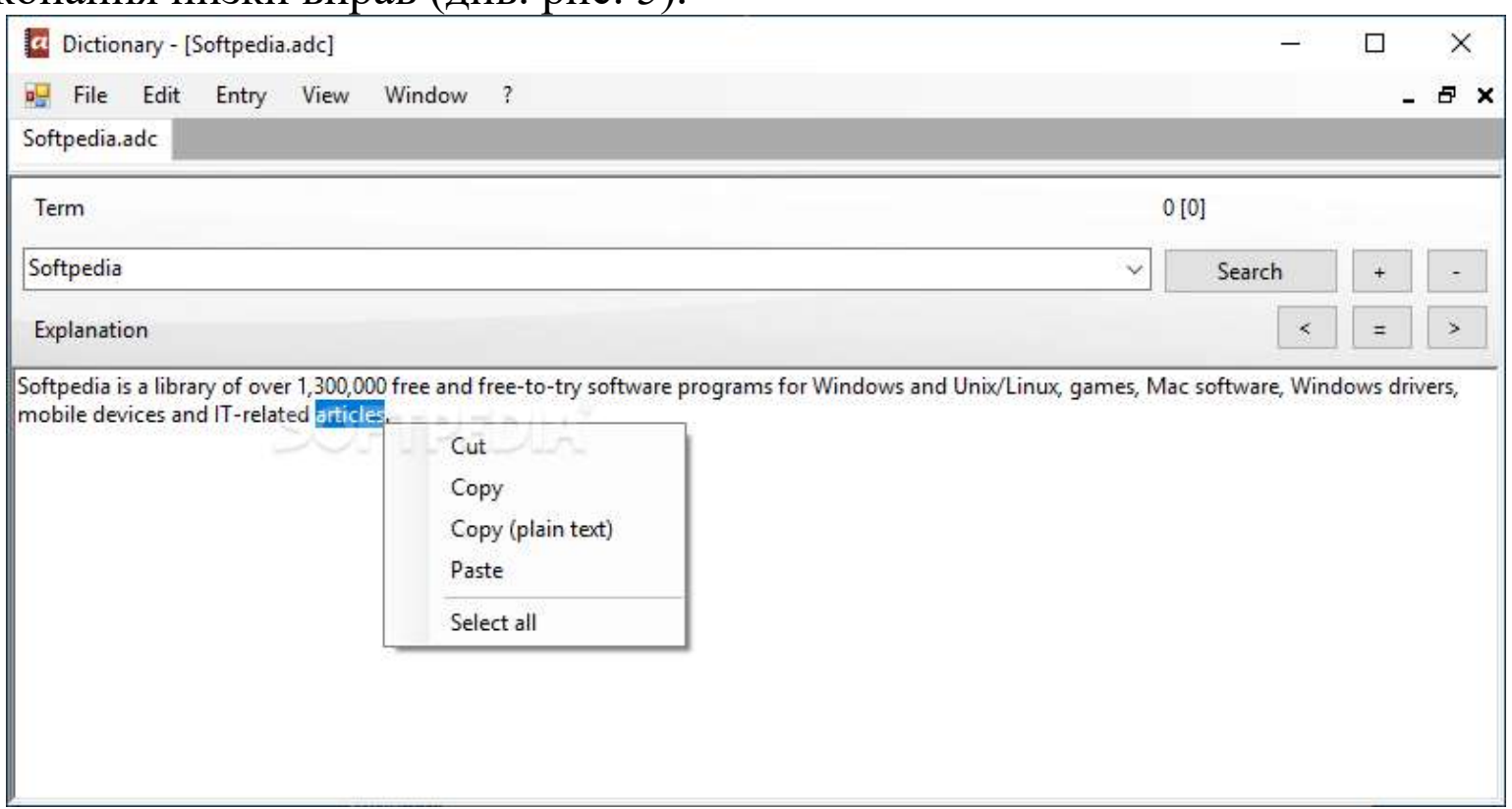

Puc. 5. Інтерфейс Alternate Dictionary 2.980

Доречним вважаємо програмний інструмент WeSay, призначений для створення словників різними мовами [18]. Конфігурація WeSay доволі проста та цілком зрозуміла для пересічного користувача (див. рис. 6). Крім того, розробники пропонують переглянути низку відео інструктажів. Цей програмний інструмент дозволяє створювати, переглядати та редагувати, додавати нові значення слова, вводити синонімію та антонімію, робити відмітку про частину мови, а також наводити приклади вживання відповідної лексеми. 


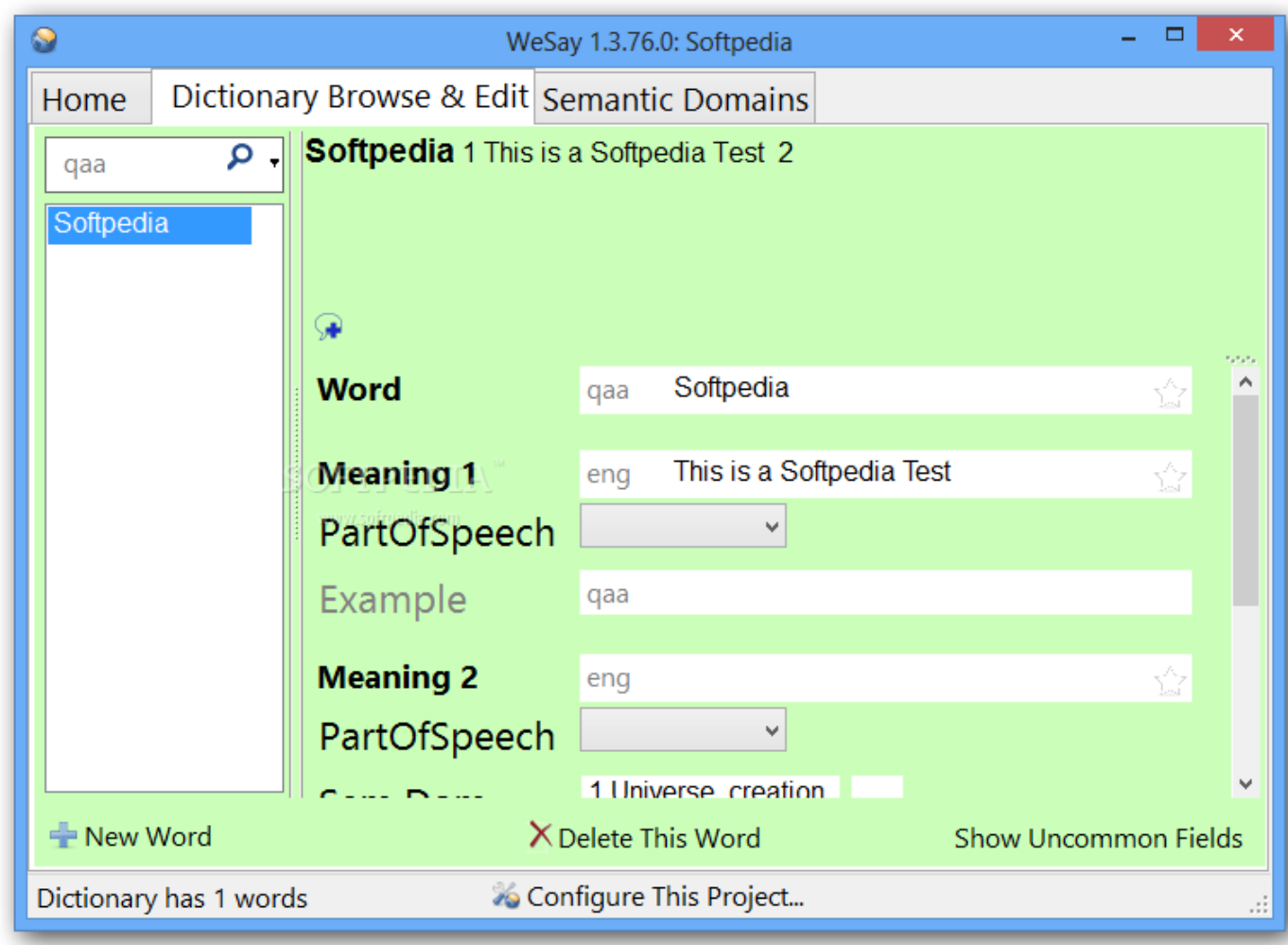

Puc. 6. Інтерфейс WeSay

Прикметною особливістю $є$ можливість відображення та звукового супроводу транскрипції відповідно до IPA. Програма дозволяє здійснювати графічне увиразнення, а саме змінювати тип та колір шрифтового наведення. Необхідну інформацію можна вивести у форматах HTML, PDF, SFM або OpenOffice.

Висновки. Таким чином, електронний багатомовний словник $є$ важливим інструментом міжкультурної наукової комунікації, а отже, існує нагальна потреба покращення засобів його створення. Розглянуті засоби укладання електронного багатомовного словника PolyDicML 3.0, TLex (Tshwanelex), Dictionary Maker, Softlex, FLEx, LingTransSoft, Lingo 4.0, Dictionary Organizer Deluxe 4.12, Alternate Dictionary 2.980, WeSay свідчать про щире бажання розробників сприяти створенню якісного лексикографічного продукту. Зазначені засоби характеризуються привабливим та зрозумілим інтерфейсом, пропонують низку необхідних функцій. Однак більшість описаних засобів передбачає створення переважно тлумачних i/aбо двомовних словників. Відповідно перспектива подальших наукових досліджень вбачається у знаходженні можливостей укладання електронного багатомовного термінологічного словника із залученням п’яти мов.

\section{Jimepamypa:}

1. Балалаєва О.Ю. Інформаційні технології як чинник формування нової парадигми освіти. Оновлення змісту, форм та методів навчання і виховання в закладах освіти. 2013. Вип. 7. С. 437-446. 
2. Білятинська I. М. Комп’ютерна лексикографія як перспективний напрямок розвитку процесу укладання словників. Прикладна лінгвістика : каталог статей конференції. 2013. [Електронний pecypc]. URL: https://prlingv.at.ua/publ/komp_juterna_ leksikografija_jak_perspektivnij_naprjamok_rozvitku_procesu_ukladannja_slovnikiv/1-1-0-7.

3. Букреева Т.В., Лукаш Е.Н. Принципы построения електронного ученого словаря французького язика. Иностр. яз. в шк., 1990. №3. С. 23-28.

4. Джонг Й. Д. Терміни НАВЧАЛЬНИЙ СЛОВНИК/УЧЕБНЫЙ СЛОВАРЬ та LEARNER'S DICTIONARY в сучасній науковій лексикографії. Актуальні проблеми української лінгвістики: теорія і практика. 2009. Вип. 18. С. 41-49. [Електронний ресурс]. URL: http://nbuv.gov.ua/UJRN/apyl_2009_18_9.

5. Кудоярова О. В., Сологуб К. С. Специфіка укладання електронних навчальних словників вузької спеціалізації (на прикладі термінології галузі автопілоту). 2016. [Електронний pecypc]. URL: https://journals.indexcopernicus.com/api/file/viewByFileId/617053.pdf.

6. Кульчицький I. М. Комп'ютерно-технологічні аспекти створення сучасних лексикографічних систем ; Укр. мов.-інформ. фонд НАН України. Київ : Нац. б-ка України ім. В. І. Вернадського НАН України, 2002. 59 с.

7. Скубюк M.В. Завдання сучасниї електроннх словників. XIV Міжнародна наукова інтернет-конференція "Advanced technologies of science and education". [Електронний pecypc]. URL: http://intkonf.org/skubyuk-mv-zavdannya-suchasnih-elektronnih-slovnikiv/.

8. Alternate Dictionary 2.980. [Електронний pecypc]. URL: https:/ /www.softpedia.com/get/Others/Home-Education/Alternate-Dictionary.shtml

9. Dictionary creation tools [Електронний pecypc]. URL: https://www.sil.org/ dictionaries-lexicography/dictionary-creation-tools?fbclid=IwAR2S_qoo3Uk4RpRUh0X3J17fC7 hn6Ib8vrkXFVFFHSNDzVpkmgwpA-FiXB4

10. Dictionary Maker 2.16 [Електронний pecypc]. URL: https://dictionarymaker.soft112.com/?fbclid=IwAR0bXwN684QBEUf6wK2FwgdX16DEVBp6519_nSQearmsEKZ 91Udgo43OHEM

11. Dictionary Organizer Deluxe 4.12. [Електронний ресурc]. URL: https://dictionaryorganizer-deluxe.software.informer.com/

12. FLEx (FieldWorks Language Explorer). [Електронний pecypc]. URL: https://www.sil.org/dictionaries-lexicography/dictionary-creationtools?fbclid=IwAR2S_qoo3Uk4RpRUh0X3J17fC7hn6Ib8vrkXFVFFHSNDzVpkmgwpA-FiXB4

13. Lingo 4.0. [Електронний pecypc]. URL: https://www.lexicool.com/soft_lingo2_overview. asp?fbclid=IwAR29nuiIT4s8DKOPT5WmqQmGhtjNa5OH-nde9emiZTTf XXSnm Bfa 0xXa72s

14. LingTransSoft. [Електронний pecypc]. URL: http://lingtransoft.info/apps/toolbox

15. The Ultimate Dictionary Making Software [Електронний pecypc]. URL: https://softleks.hr/wp/products/softlex/?fbclid=IwAR09y08fXkPV2Z0C62BkUHArrX9T3cOdodG 05ohT-BXQQIm7D--25ThWzqc

16. TLex (TshwaneLex) [Електронний pecypc]. URL: https://tshwanedje.com/ tshwanelex/?fbclid=IwAR3RUGSJuAGI0ITBxqdUiWTbiQvb3QPGWEqKiwRdg5SsCtUDAIZBr xAQdX8

17. TLex Electronic Dictionary. [Електронний ресурc]. URL: https://tshwanedje.com/ electronic/?fbclid=IwAR1zveKvsco9-tbj7lhNm9ofAMAJiS2DesLx0W6BjfoMiNVzqKtE3RZItTI

18. WeSay. [Електронний ресурc]. URL: https://www.softpedia.com/get/Others/HomeEducation/WeSay.shtml

\section{References:}

1. Balalaieva O.Iu. Informatsiini tekhnolohii yak chynnyk formuvannia novoi paradyhmy osvity [Information technologies as a factor in the formation of a new paradigm of education] 
Onovlennia zmistu, form ta metodiv navchannia i vykhovannia v zakladakh osvity. 2013. Vyp. 7. S. 437-446. [in Ukrainian].

2. Bilyatyns'ka I. Komp'yuterna leksykohrafiya yak perspektyvnyj napryamok rozvytku procesu ukladannya slovnykiv [Computer lexicology as a promising direction of compiling dictionaries] Prykladna linhvistyka : kataloh statej konferenciyi. 2013. URL: https://prlingv.at.ua/publ/komp_juterna_ leksikografija_jak_perspektivnij_naprjamok_rozvitku_procesu_ukladannja_slovnikiv/1-1-0-7.

[in Ukrainian].

3. Bukreeva T.V., Lukash E.N. Principy postroenija jelektronnogo uchenogo slovarja francuzskogo jazika [The structure of electronic French dictionary] Inostr. jaz. v shk., 1990. №3. S. 23-28. [in Russian].

4. Dzhonh Y. D. Terminy NAVCHALNYI SLOVNYK/UCHEBNYI SLOVAR ta LEARNERS DICTIONARY v suchasnii naukovii leksykohrafii [Learners' dictionary in modern lexicography] Aktualni problemy ukrainskoi linhvistyky: teoriia i praktyka. 2009. Vyp. 18. S. 4149. Retrieved from http://nbuv.gov.ua/UJRN/apyl_2009_18_9. [in Ukrainian].

5. Kudoiarova O. V., Solohub K. S. Spetsyfika ukladannia elektronnykh navchalnykh slovnykiv vuzkoi spetsializatsii (na prykladi terminolohii haluzi avtopilotu) [Specifics of compiling electronic training dictionaries of narrow specialization (on the example of autopilot terminology)] 2016. Retrieved from https://journals.indexcopernicus.com/api/file/viewByFileId/617053.pdf. [in Ukrainian].

6. Kul'chyc'kyj I. M. Komp'yuterno-texnolohichni aspekty stvorennya suchasnyx leksykohrafichnyx system [Computer-technological aspects of creating modern lexocgraphic systems] Ukr. mov.-inform. fond NAN Ukrayiny. Kyyiv : Nac. b-ka Ukrayiny im. V. I. Vernads'koho NAN Ukrayiny, $2002.59 \mathrm{~s}$. [in Ukrainian].

7. Skubiuk M.V. Zavdannia suchasnyi elektronnkh slovnykiv. KhIV Mizhnarodna naukova internet-konferentsiia "Advanced technologies of science and education". Retrieved from http://intkonf.org/skubyuk-mv-zavdannya-suchasnih-elektronnih-slovnikiv/. [in Ukrainian].

8. Alternate Dictionary 2.980. Retrieved from https://www.softpedia.com/get/ Others/Home-Education/Alternate-Dictionary.shtml [in English].

9. Dictionary creation tools. Retrieved from https://www.sil.org/dictionarieslexicography/dictionary-creation-tools?fbclid=IwAR2S_qoo3Uk4RpRUh0X3J17fC7hn6Ib8 vrkXFVFFHSNDzVpkmgwpA-FiXB4 [in English].

10. Dictionary Maker 2.16. Retrieved from https://dictionary-maker.soft112.com/ ?fbclid=IwAR0bXwN684QBEUf6wK2FwgdX16DEVBp6519_nSQearmsEKZ91Udgo43OHEM [in English].

11. Dictionary Organizer Deluxe 4.12. Retrieved from https://dictionary-organizerdeluxe.software.informer.com/ [in English].

12. FLEx (FieldWorks Language Explorer). Retrieved from https://www.sil.org/ dictionaries-lexicography/dictionary-creation-tools?fbclid=IwAR2S_qoo3Uk4RpRUh0X3J17fC7 hn6Ib8vrkXFVFFHSNDzVpkmgwpA-FiXB4 [in English].

13. Lingo 4.0. Retrieved from https://www.lexicool.com/soft_lingo2_overview.asp? fbclid=IwAR29nuilT4s8DKOPT5WmqQmGhtjNa5OH-nde9emiZTTfXXSnmBfa0xXa72s [in English].

14. LingTransSoft. Retrieved from http://lingtransoft.info/apps/toolbox [in English]

15. The Ultimate Dictionary Making Software. Retrieved from https://softleks.hr/wp/products/softlex/?fbclid=IwAR09y08fXkPV2Z0C62BkUHArrX9T3cOdodG 05ohT-BXQQIm7D--25ThWzqc [in English].

16. TLex (TshwaneLex). Retrieved from https://tshwanedje.com/tshwanelex/?fbclid= IwAR3RUGSJuAGIOITBxqdUiWTbiQvb3QPGWEqKiwRdg5SsCtUDAIZBrxAQdX8 [in English].

17. TLex Electronic Dictionary. Retrieved from https://tshwanedje.com/electronic/ ?fbclid=IwAR1zveKvsco9-tbj7lhNm9ofAMAJiS2DesLx0W6BjfoMiNVzqKtE3RZItTI [in English].

18. WeSay. Retrieved from https://www.softpedia.com/get/Others/Home-Education/ WeSay.shtml [in English]. 